\title{
INTEGRATED MARKETING COMMUNICATIONS ACTIVITIES OF REDDOORZ INDONESIA: A STRATEGY TO PRESERVE THE BUSINESS DURING COVID-19 PANDEMIC
}

\author{
Natalina NILAMSARI*, Alfitra FEBRYANSYAH, and Rialdo RL TORUAN \\ Faculty of Communication, Universitas Prof.Dr.Moestopo(Beragama) \\ "natalinanilamsari@dsn.moestopo.ac.id
}

\begin{abstract}
The online budget hotel business has grown since 2015, became a new primadona in 2019 and was forced to lay down due to the pandemic hit the whole world in 2020. One of the budget hotel network that can survive is RedDoorz. This study aims to analyze the integrated marketing communication activities which is conducted by the management of RedDoorz Indonesia as a strategy to preserve the business during the pandemic. Research designed was qualitative descriptive. The data was transcripts of interviews with the Country Marketing Head and Public Relations Manager of RedDoorz, observation records, and literature searches from online mass media were processed by the analysis guidance of Miles and Huberman's interactive model. The results of the study found that the integrated communication activities performed by RedDoorz Indonesia as a strategy to preserve the virtual hotel operator business during the pandemic included: 1) advertising configuration was billboard until 2020;2)publicity and public relations in the form of collaboration with the Indonesian Association of Public Health Experts to issue HygienePass certificates for properties that invited to cooperate and educate on health protocols acquired publicity in online media; 3)sales promotion format was discount promotion, 4)personal selling format was word of mouth (WoM) by personal social media employees/partners of property owners, 5)direct marketing by means of telephone management directly to consumers, 6)interactive marketing by means of Mobile Apps and social media.
\end{abstract}

Keywords: Budget Hotel, Integrated Marketing Communication, Strategy, Virtual Hotel Operator

\section{BACKGROUND}

During the Covid-19 pandemic, tourism has become one of the sectors that had been severely affected. Entertainment venues, tourist and culinary destinations as well as accommodation and hostelry must adapt or closed due to the pandemic and the mobility restriction policies implemented. Data from the Indonesian Hotel and Restaurant Association (PHRI) as of April 5, 2020, a number of 1,642 hotels throughout Indonesia were forced to close due to the pandemic.

A year into the pandemic, tourism in Indonesia is gradually revived with various adaptations. Hotel entrepreneurs undertake a lot of innovation to survive, for example, proffer a work from hotel staycation package, so that people can work while on vacation. Whether render the hotels as accommodation facilities for people without symptoms who are self-isolating.

In addition to those efforts, the hotel management can undertake a communication strategy to preserve the business continuity during the pandemic. One or other variety of the hotel that can preserve the business continuity during the pandemic is RedDoorz Indonesia. Therefore, this paper aims to analyze the integrated marketing communication activities performed by RedDoorz Indonesia, as a strategy to preserve the business during the pandemic.

In accordance with Four AS (The American Association of Advertising Agency) quoted by Bayquni (2010), Integrated Marketing Communication is a marketing communications planning concept that recognizes value-added of a comprehensive plan, examines the strategic role of communication configuration-such as advertising, direct response, promotion, sales and public relations-integrate them to seize clarity, consistency and maximum communication impact through message integration. In line with that, Rahmadi dan Quraisyin (2015) express Integrated Marketing Communication is a marketing communication planning concept that adds value to an exhaustive scheming by evaluating the strategic role of variety communication sciences, and integrate them to deliver accuracy, consistency and maximum communication effect through the integration of separate messages.

Integrated Marketing Communication integrates all elements of the promotion mix, assuming there is no separate element to realize effective marketing objectives. On SRJ Marketing Communications website (https:// www. srj.net) mentioned that there are 6 steps in the planning process of Integrated Marketing Communication i.e. 1) know your target audience, 2) develop a situation analysis, 3) determining marketing communication objectives, 4) determining budget, 5) strategies and tactics in specific action, 6) evaluation and measurement.

Kotler and Armstrong (2010) express five elements of marketing communications included in Integrated Marketing Communication i.e : 1)advertising, 2) public relations, 3)personal selling, 4)sales promotion, 5) direct selling. Whereas Belch and Belch (2015) enhance of the five elements related to technology, viz interactive marketing through internet marketing. In line with that, Sumiyati and Murdiyanto (2018) express additional elements in marketing communication, namely: selling, advertising, sales promotion, direct selling, publicity and public relations, sponsorship, packaging, exhibition, point of sale and merchandise, word of mouth, e-marketing, corporate identity. A good Integrated Marketing Communication is a communication design that is not responded unsavory by consumers.

Therefore it can be said that integrated marketing communication is a marketing communication concept 
that can be carried out through a comprehensive and consistent series of activities from elements of marketing, advertising, publicity and public relations to acquire a positive response from the audience or consumers.

Refers to The Statute Number 20/2009 with reference to Tourism there is no term low budget or budget hotel. Budget hotel is the term for the hotel category with facilities equivalent to one-star to three-star hotels. Guests at budget hotels do not have to spend more money on facilities they not required, such as swimming pool or other entertainment facilities (Rahma, 2017). In other words, budget hotel is a hotel or hostelry at low rates because they provide rooms with standard facilities.

In line with technological development in the sector of accommodation, one of this businesses that is quite fast is sharing economy business model (Psarros et.al , 2014; Ivanova, 2015 ; Gunawan et.al , 2019), that is business model when someone can distribute assets that are idle or have not been utilized optimally for economic interests, and/or social benefits. In the last ten years, the sharing economy system in the accommodation business has increased, marked by the emergence of virtual hotel operators (VHOs) such as OYO Rooms, Airy, RedDoorz and Zen Rooms (Gunawan et.al 2019).

VHO is a hotel operator that cooperates with various hotels, in general with budget hotels. However, currently they are also collaborating with villas or four stars hotels and above, to provide better standard of facilities and quality of service to residents. VHO was originally known as a hotel aggregator service that facilitate for tourists to reserve an inexpensive rooms. VHO first popular in India and became known in Indonesia in 2015(Kusumawati 2020).

Basically, VHO is a technology company that has an impact on the hospitality business around the world (Jayawardena 2013). The basic concept of VHO is rebranding for hotel or shelter owners or other properties who want to join. Each VHO has their own operational standards as a checklist for their partners. Jazila (2019) express that before a hotel or property joins the listing, VHO will send a team to check the eligibility.The inspection involve the facilities and services. After being approved, then the property rebranded and offered to the public. Hotels that merge with franchise system, will be settle up a commission to the $\mathrm{VHO}$ according to the number of rooms rented. Meanwhile, property owners who submit their management in full operated, will receive profit sharing according to the agreement, whether the room was occupied or not (Jazila 2019, Kusumawati 2020).

\section{METHOD}

The type of research was descriptive qualitative. The data were obtained by: 1) administer interviews with the sources which have been specified, specifically the Country Marketing Head and Public Relations Manager of RedDoorz Indonesia; 2) make a record on observations and quest for articles in the media online about RedDoorz during the pandemic. After the data collected then analyzed seize the interactive model's of Miles and Huberman (2005) as explained by Sugiyono (2014) in order: 1) data reduction, the collected data were sorted based on the research objectives; 2) data display, the data were presented in narrative form; 3) conclusion drawing and verification, findings and verification were carried out interactively and then conclusions were obtained

\section{RESULT AND DISCUSSION}

RedDoorz was established in Singapore and entered Indonesia in 2015. Based on the records of media online quest, it can be said that RedDoorz is one of the leading inn/budget hotel network and virtual hotel operators in Indonesia (see Table 1)

Table 1 Quest of news content from media online

\begin{tabular}{|c|c|}
\hline & \\
\hline $\begin{array}{l}\text { https://www.w a r t a e k o n o mi.co.id/ } \\
\text { read263144/hotel-budget-di-indonesia-jadi- } \\
\text { primadona-baru }\end{array}$ & $\begin{array}{l}\text { The growth of } \\
\text { budget hotels in } \\
\text { Indonesia }\end{array}$ \\
\hline $\begin{array}{l}\text { http s:// e k o n o m i. bis n is . c o m / } \\
\text { read/20190708/12/1121417/mulai-oyo- } \\
\text { airy-hingga-reddoorz-simak-tren-virtual- } \\
\text { hotel-operator-di-indonesia }\end{array}$ & $\begin{array}{l}\text { Virtual hotel } \\
\text { operator trend in } \\
\text { Indonesia }\end{array}$ \\
\hline $\begin{array}{l}\text { https://www.cnnindonesia.com/ } \\
\text { teknologi/20170127074904-206-189388/ } \\
\text { reddoorz-penyedia-jaringan-hotel-budget- } \\
\text { terbesar }\end{array}$ & $\begin{array}{l}\text { RedDoorz as the } \\
\text { largest budget hotel } \\
\text { networks provider } \\
\text { in Indonesia }\end{array}$ \\
\hline $\begin{array}{l}\text { https://www.merdeka.com/uang/inovasi- } \\
\text { hotel-bertahan-di-tengah-pandemi- } \\
\text { covid-19.html }\end{array}$ & $\begin{array}{lr}\text { Hotel innovation } \\
\text { persists during } \\
\text { pandemic }\end{array}$ \\
\hline $\begin{array}{l}\text { https://industri.kontan.co.id/news/perluas- } \\
\text { jaringan-reddoorz-kini-jalankan-sembilan- } \\
\text { properti-sans-hotel-di-indonesia }\end{array}$ & $\begin{array}{l}\text { RedDoorz expand } \\
\text { the network during } \\
\text { pandemic }\end{array}$ \\
\hline
\end{tabular}

According to the VHO concept, RedDoorz Indonesia focuses on hostelry development and online sales distribution. In the implementation of the activities, according to the concept of Jazila (2019) and Kusumawati (2020), RedDoorz Indonesia assort the potential properties for direct collaboration/cooperation and committed to the RedDoorz brand. Property owners then assisted to improve the quality of their hostelry in terms of facilities and services, by means of minimal standards specifically clean linen, free Wi-Fi, mineral water, Air Conditioner, clean toilet, towels, water heater, and 24/7 service.

In 2016 RedDoorz straggle to five major cities in Indonesia and RedDoorz properties grew eleven times. A year later, RedDoorz Indonesia already has 500 hostelry. In 2018 the number of RedDoorz rooms spread throughout Indonesia was 10,000. In 2018 RedDoorz also started to step in Philippines and Vietnam. In 2019 RedDoorz grew rapidly in 50 cities in Indonesia with more than 1,000 properties and more than 30,000 rooms. This year RedDoorz also started to expand the business in the field of Co-Living.

As well known, the RedDoorz business experienced severe obstacles in 2020 when the Covid-19 Pandemic rocked the tourism industry around the world. RedDoorz 
strives to survive by implementing all communication and marketing strategies and tactics to the consumers and partners. In addition, RedDoorz makes adaptation efforts for business continuity.

Based on the analysis, it can be said that RedDoorz Indonesia performed integrated marketing communication, which is carried out through a comprehensive and consistent sequence of activities: marketing, advertising, publicity and public relations elements to obtain positive responses from audiences or consumers with a six-steps Integrated Marketing Communication planning process.

The six steps of the planning process performed by RedDoorz Indonesia namely:

1) Know target audience.

The management of RedDoorz Indonesia conducted an analysis of the potential target market, specifically people who still have to travel because of the job, whereas the pandemic situation. Many people occupation's like sales and marketing still have to travelling. They need clean lodging and guarantee health protocols. In a pandemic situation, many companies deduct the travel budgets including accommodation budgets. The option of the accomodation with economical prices, clean and comfortable occur the preference of consumers. RedDoorz saw this opportunity based on the target audience analysis.

2) Develop a situation analysis.

The management of RedDoorz Indonesia conducted an analysis of the situation related to the pandemic. The results obtained that health protocols must be the focus of the facilities and services of all properties whose members of RedDoorz Indonesia. Likewise, the opportunities of RedDoorz services before the pandemic at the aspect: convenience to finding rooms and destination locations by online, competitive prices, ease of reservation, convenience and ease of check-in and check-out processes. Service and hotel quality of the RedDoorz network which is quite good formed strength of the business for RedDoorz Indonesia to survive during the pandemic.

3) Determining marketing communication objectives. The objectives of every marketing communication efforts be made as clear as possible. For example, based on point 2), public relations in collaboration with The Indonesian Association of Public Health Experts (IAKMI) issues a HygienePass certificate. This certificate given to all RedDoorz Indonesia network hotels/properties that strictly implement hygiene and sanitation as well as health protocols in their hotel environment. This is a design guarantee of cleanliness and hygiene to consumers in the interest of safety and comfortable during the pandemic.

4) Determining budget

The pandemic caused a decrease in occupancy throughout RedDoorz Indonesia's network. January 2020, the occupancy rate was 57 percent. March
2020 it fell even more only 21 percent. Therefore, the management has delimitation of the media operational budget for promotions, and deduct the salaries of senior employees up to 75 percent.

5) Strategies and tactics in specific action

RedDoorz Indonesia realizes that in a crisis situation due to the pandemic, the companies must adapt smartly.

Based on the elaboration of the Integrated Marketing Communication concept by Kotler-Armstrong (2010) and Belch and Belch (2015), RedDoorz Indonesia performed five elements of marketing communication included in integrated marketing communication, specifically:

a)advertising.

Before the pandemic, for example, RedDoorz had lease right of billboards in Cirebon area and still continue during the pandemic until the end of 2020. Billboards are considered as the best way to maintain consumer knowledge about product information.

b) public relations and publicit.y

In terms of Public Relations and publicity, RedDoorz Indonesia carries out a sequence of health protocol education activities as well as the promotion of HygienePass certificates as a design guarantee for consumers comforting during the pandemic. The publicity of this activity was published in online media.

c) personal selling.

Management of RedDoorz Indonesia encourages every employee and people who work in hotels/property in they network to do word of mouth(WoM) with potential customers. Physical restrictions during the pandemic, make them create personal messages through personal social media such as WhatsApp, Instagram or Twitter. They were encouraged to tell about property facilities and services, health protocol guarantees or discounts provided.

This procedure were considered more adaptive and applicable. In some locations, this procedure has proven to be effective in attracting consumers to stay on the RedDoorz hostelry network

d) sales promotion

RedDoorz realizes that during the pandemic, people's purchasing power decreases. In addition, restrictions on mobility prevent people from traveling.

However, sales promotions in the form of price discounts still being carried out as a tactic to keep businesses survive during the pandemic. Business that offer discounts can increase reputation, because they considered support the society that have financial distress to pay for their needs. Discount Promos make RedDoorz considered as a business that pay attention for helping people during the pandemic.

e) direct selling.

The management of RedDoorz Indonesia immediately go straight down to direct selling. They called customers 
directly, asking if there is a possibility that some of those customers have to travel and need suitable accommodation.

Direct selling was a personalized approach for each customer. In the manner of direct selling, each customer's reaction and feedback can be captured instantly. By direct selling, companies can build healthy relationships with customers and increase customer satisfaction.

f) interactive marketing.

Interactive marketing is a marketing method in which consumers directly involved and expect an immediate response from the company to fulfill their needs. The communication strategy is two-way. Prior to the pandemic, RedDoorz had installed mobile Apps for android and iOS. Mobile Apps is an applications that are created, installed and operated on smartphones or tablets on various platforms. Mobile Apps important for online business. The features customized to business needs. At the same time consumers can easily, quickly, efficiently and safely to access the products they need. During a pandemic Mobile Apps became of the spearheads of RedDoorz Indonesia in serving the consumers. Furthermore, RedDoors done the interactive marketing, through social media because of the characteristics specifically quickness and two-way communication.

6) Evaluation and measurement.

RedDoorz Indonesia has measured and evaluated all aspects of integrated marketing communication, to preserve the business. It can be said that RedDoorz Indonesia, under the network of hostelry, has carried out strategies and tactics that are right on target.

In line with Mangeswuri (2021) stated that the occupancy rate of star-classified hotel rooms in February 2021 averaged down 16.82 points on an annual basis. However, when compared to January 2021, the room occupancy rate in February 2021 increased by 2.05 points. Non-star hotels recorded growth in terms of room occupancy rates and length of stay of guests during February 2021 compared to star hotels.

\section{CONCLUSION}

During the 2020 pandemic, RedDoorz Indonesia carried out strategies and tactics as a form of adaptation so that the business continue. In 2021 RedDoorz Indonesia will remain the business, by performed integrated marketing communication activities in the form of:

1) advertising in the form of billboards until 2020 ,

2) publicity and public relations in the form of collaboration with the Indonesian Association of Public Health Experts to issue HygienePass certificates for properties that are invited to cooperate and educate protocols health gets publicity in online media,

3 ) sales promotion in the form of discount promotions, 4) personal selling in the form of word of mouth via personal social media of employees/partners of property owners,

5) direct marketing by telephone directly from the management to consumers,

6) interactive marketing through Mobile Apps and social media.

All these activities are carried out according to government directives so that tourism and hotel business managers are disciplined in maintaining health protocols in the new era of the pandemic and have a CHSE (Clean, Health, Safety and Environmental Sustainability) certificate.

\section{REFERENCES}

Bayquni. 2010. Memahami bergerilya lewat komunikasi pemasaran. Wacana, Jurnal Ilmiah Ilmu Komunikasi. Vol 9(4), 1-14

Belch, George E and Michael A Belch. 2015. Advertising and Promotions: An Integrated Marketing Communications Perspectives. $10^{\text {th }}$.Ed. McGrawHill Irwin, Boston.

Diayudha, Lanang. 2020. Industri perhotelan di Indonesia pada masa pandemi Covid-19: analisis deskriptif. Jurnal FAME, vol 3(1), 41-45

Gunawan, E, Gabriel O Sebastian, Agung Harianto. 2019. Analisa Pengaruh Kualitas Layanan terhadap Kepuasan pelanggan menginap di empat Virtual Hotel Operator di Surabaya. Journal of Indonesian Tourism, Hospitality and Recreation Vol 2(2),145153.

Ivanova, Maya G. 2015. Sharing economy: Bulgarian Tourism Industry Perspective. Proceeding of International Conference 'Tourism in The Age Of Transformation, 5-7 November 2015. Varna, University of Economics-Varna, pp 479-488.

Jazila, H. 2019. Virtual Hotel Operator: pengertian dan cara kerja. https://www.pikirantrader.com/bisnis/9681virtual-hotel-operator-pengertian-dan-cara-kerja.

Jayawardena, C. 2013. Trends in The International Hotel Industry. Worldwide Hospitality and Tourism Themes. 5(2), 151-163.

Kotler, Philip and Garry Armstrong. 2010. Principles of Marketing. $13^{\text {th }}$ ed. Pearson, USA.

Kusumawati, Fitri. 2020. Tren Virtual Hotel Operator (VHO) di Yogyakarta (Studi Kasus Hotel OYO). Media Wisata Vol 18(1),90-100

Mangeswuri, Dewi Restu. 2021. Prospek peningkatan pariwisata domestic di tengah pandemi Covid-19. Info Singkat vol XIII No7/I/Puslit/April/2021

Miles, Matthew and A. Michael Huberman. 2005. Qualitative Data Analysis. UI-Press, Jakarta. 
Psarros, M.,A Rinne, P Jordan, P. Pastrats. 2014. Sharing Economy and The Tourism and Hospitality Sector in Greece. Hellenic Chamber of Hotels.

Rahma, Fajar Nuur Alfie.2017. Desain interior budget hotel untuk backpacker dengan konsep persahabatan Asia. repository.its.ac.id/45818/1/3813100030/ undergraduate theses.pdf

Rahmadi, Ipin dan Dewi Quraisyin. 2015. Penerapan Integrated Marketing Communication di media Radio Segara FM Bangkalan. Komunikasi IX(01), 83-94.
Sugiyono. 2014. Metode Penelitian Kuantitatif, Kualitatif dan Kombinasi (Mixed Methods). Alfabeta, Bandung

Sumiyati, Lilik Murdiyanto. 2018. Strategi komunikasi pemasaran pariwisata untuk meningkatkan kunjungan wisatawan di Pantai Suwuk Kabupaten Kebumen. Wacana, Jurnal Ilmiah Ilmu Komunikasi Vol.17(2), 171-180 